\title{
Pulmonary hematological parameters, energetic flight demands and their correlation with oxygen diffusion capacity in the lungs
}

\author{
Parámetros hematológicos pulmonares, demandas energéticas del vuelo y su correlación la \\ capacidad de difusión de oxígeno en los pulmones
}

M. CANALS ${ }^{1, *}$, C. DONOSO, D. FIGUEROA \& P. SABAT $T^{1,2}$

\begin{abstract}
${ }^{1}$ Laboratorio de Ecofisiología Animal, Departamento de Ciencias Ecológicas Universidad de Chile
${ }^{2}$ Center for Advanced Studies in Ecology \& Biodiversity, Pontificia Universidad Católica de Chile

*E-mail for correspondence: mcanals@uchile.cl
\end{abstract}

\begin{abstract}
Hematological parameters of birds and mammals seem to respond to environmental requirements, such as hypoxia at high altitude and the energetic demands of locomotion and flight. In this work we hypothesize that lung capillary hematocrit and red blood size may be influenced by the energetic requirements of flight. Also, we propose that hematological parameters should vary together with the morphological parameters that determine oxygen diffusion capacity. We analyzed the red blood cell size and the local characteristics of the pulmonary capillary hematocrit correlating these with the pulmonary factors that determines the oxygen diffusion capacity. We deal with seven species, non-flying and flying birds and mammals, with different energetic requirements. The capillary hematocrit was not different in each taxon, but the red blood cell size was smaller in flying mammals and birds than non-flying ones. Correlation of erythrocyte size with the diffusing characteristics of the lungs produced a non-phylogenetic clustering with a group constituting by the bats Tadarida brasiliensis y Myotis chiloensis, and the bird Z. auriculata; revealing similar functional response in unrelated species. Finally, in mammals, a negative correlation between the red blood cell size and the mass-specific oxygen diffusion capacity was obtained. These results suggest that the direction of the hematological and pulmonary adjustments is governed mainly by the requirements of flight independent of phylogenetic origin of the species studied.
\end{abstract}

Key words: cost of flight, capillary hematocrit, red blood cell size, oxygen diffusion capacity

\section{RESUMEN}

Los parámetros hematológicos y pulmonares parecen responder a las exigencias ambientales como la hipoxia y la alta altitud y a los requerimientos energéticos de la locomoción. En este trabajo sometemos a prueba la hipótesis que el hematocrito del capilar pulmonar y el tamaño del glóbulo rojo pueden ser influidos por los requerimientos energéticos del vuelo. También proponemos que los parámetros hematológicos varían en conjunto con los parámetros que determinan la capacidad de difusión de oxígeno. Analizamos el tamaño del glóbulo rojo y las características locales del hematocrito capilar pulmonar correlacionándolos con los factores pulmonares que afectan la capacidad de difusión de oxígeno. Analizamos siete especies de diferente requerimiento energético, corredoras y voladoras. El hematocrito capilar pulmonar no mostró diferencias significativas en aves ni en mamíferos. El tamaño del glóbulo rojo fue menor en los mamíferos y en aves voladoras con respecto a sus pares no voladores. La respuesta conjunta del glóbulo rojo, la superficie respiratoria y la membrana alvéolo-capilar mostró un agrupamiento no filogenético donde se destaca un cluster constituido por mamíferos y aves de vuelo activo (dos murciélagos: Tadarida brasiliensis y Myotis chiloensis y la tórtola Zenaida auriculata). Finalmente, en mamíferos se obtiene una relación inversa entre la capacidad de difusión de oxígeno y el tamaño del glóbulo rojo. En definitiva, los hallazgos sugieren la existencia de ajustes funcionales hematológicos y pulmonares como una respuesta conjunta a las exigencias del vuelo, independientes de su origen filogenético.

Palabras clave: costo de vuelo, hematocrito capilar, tamaño glóbulos rojos, capacidad difusión de oxígeno. 


\section{INTRODUCTION}

Hematological parameters of birds and mammals seem to respond to environmental requirements, such as hypoxia at high altitude and the energetic demands of locomotion and flight (Novoa et al. 2002). For example, a lower mean cell volume of erythrocytes was reported for small high altitude mammals (Thomomys) than for mammals living at sea level (Lechner 1976). Similarly Rosenmann \& Ruiz (1993) reported that Abrothrix andinus (Phillipi, 1858)which dwells over $2.000 \mathrm{~m}$ of altitude, have high red blood cell counts, increased blood hemoglobin concentration and significant decrease in mean cell volume during seasons of high energetic requirements, while the hematocrit remains constant throughout the year. Also, the hematocrit of resident high altitude species has been reported to be similar to that of species which inhabit low elevations (Morrison et al. 1963a, 1963b, Rosenmann \& Ruiz 1993). In birds, which have a high tolerance to hypoxia (Novoa et al. 1991), the hematological response to high altitude is still controversial. In native high-altitude birds some authors have shown higher blood hemoglobin concentrations, red blood counts (Carey \& Morton 1976) and hematocrits than for birds of low altitude (Carey \& Morton 1976, Keys et al. 1986). However other authors have been reported similar hematological parameters but differences in hemoglobin oxygen affinity (Black \& Tenney 1980). Carpenter (1975) and Viscor et al. (1985) argued that the hematocrit of bird is more related to flight than to altitude distribution.

Hematological parameters respond to environmental and energetic demands together with respiratory and cardiovascular modifications, rather than in an isolate form (Carey \& Morton 1976, Viscor et al. 1985, Viscor \& Fuster 1987). Regarding flight demands, birds exhibit several adaptive features such as an efficient cross-current system in their air way, large tidal volume, short pulmonary circulatory time which maximizes the utilization of hematological factors in gas uptake, large respiratory surface areas and thin air-blood barrier (Maina 1998, 2000a, 2000b, Figueroa et al. in press). Similarly, bats show a number of refinements in the design of the cardiovascular and respiratory systems, which include: large heart and cardiac output (Canals et al. 2005a,
Jurgens et al. 1981); small erythrocytes (Wolk \& Bogdanowics 1987, Neuweiler 2000), high concentrations of hemoglobin and high oxygen transport capacity (Wolk \& Bogdanowics 1987); and optimization of structural lung parameters such as lung volume, density of the respiratory surface and thickness of the alveolar-capillary barrier (Lechner 1985, Maina 1998, 2000a, 2000b, Maina et al. 1991, Canals et al. 2005b, Figueroa et al. in press).

In the lung the hematological parameters can vary by the particulate nature of the blood passing through a complex network of capillaries (Baumgartner et al. 2004) and due to differences in the relative speed of plasma and erythrocytes (Rapaport et al. 1996, Hsia et al. 1999). A progressive increase of about two-to three-fold of pulmonary diffusion capacity from rest to exercise has also been reported (Hsia et al. 1995, 1999). These particular behavior of the erythrocytes in the lung capillaries, suggests that it is possible a different response of capillary blood hematocrit in species with different energetic requirements. In this work we hypothesize that lung capillary hematocrit and red blood size may be influenced by the energetic requirements of flight. Also, we propose that hematological parameters should vary together with the morphological parameters that determine oxygen diffusion capacity.

\section{MATERIAL AND METHODS}

We studied five mammals and two bird species. We included two bats (flying mammals), Myotis chiloensis (Waterhouse, 1838) $\left(\mathrm{M}_{\mathrm{b}}=6.05 \pm 0.10\right.$ $\mathrm{g}$ (mean $\pm \mathrm{SD}) ; \mathrm{n}=3$ ) and Tadarida brasiliensis (Geoffroy Saint Hilarie, 1824) $\left(\mathrm{M}_{\mathrm{b}}=\right.$ $11.3 \pm 0.5 \mathrm{~g} ; \mathrm{n}=4)$ and three non-flying mammals, Phyllotis darwini (Waterhouse, 1837) $\left(\mathrm{M}_{\mathrm{b}}=75.36 \pm 4.96 \mathrm{~g}, \mathrm{n}=3\right)$ Abrothrix olivaceus (Waterhouse, 1837) $\left(\mathrm{M}_{\mathrm{b}}=26.3 \pm 2.0 \mathrm{~g}, \mathrm{n}=3\right.$ ) and Abrothrix andinus. $\left(\mathrm{M}_{\mathrm{b}}=25.5 \pm 1.9 \mathrm{~g}, \mathrm{n}=\right.$ 3) Our bird models were Zenaida auriculata (Des Murs, 1847) $\left(\mathrm{M}_{\mathrm{b}}=141.1 \pm 1.55\right.$ g., $\left.\mathrm{n}=3\right)$ an active flying species and Nothoprocta perdicaria (Kittlitz, 1830) $\left(\mathrm{M}_{\mathrm{b}}=398.33 \pm 11.70\right.$ $\mathrm{g}, \mathrm{n}=3$ ) a species that fly sporadically. All birds and rodents individuals used in this study were caught with Sherman traps or mist nets and immediately transported to the laboratory during 
spring and summer between 2003 and 2005. The bats were donated by the Institute of Public Health from Chile. Animals were weighed and then killed by means of $100 \% \mathrm{CO}_{2}$ exposure or by an overdose of anesthetic by intraperitoneal injection following the guidelines of the Ethical Committee of the Faculty of Sciences of the University of Chile. The trachea were exteriorized and cannulated. In the case of birds we avoided injection into the air sacs. A quantity of $2.3 \%$ glutaraldehyde in phosphate buffer $(\mathrm{pH}$ 7.4) was introduced in the trachea (Maina 2002a). When the fixative solution exceeded the level of the trachea, we closed it and tied it to the cannula. Immediately following this procedure, the lungs were removed and immersed in the same fixative at $4{ }^{\circ} \mathrm{C}$ for a minimum of $2 \mathrm{~h}$. Next, tissues (right and left lungs) were processed for routine electron transmission microscopy. Briefly, two pieces of 1-2 mm thickness were obtained from each lobe in mammals and four randomly chose pieces were obtained from each lung of birds. The pieces were washed with buffer and post-fixed with $1 \%$ osmium tetroxide for 1 hour at $4{ }^{\circ} \mathrm{C}$. Tissues were then dehydrated in graded concentrations of alcohol and infiltrated and embedded in epoxy resin constructing cubes of 2-3 $\mathrm{mm}^{3}$, obtaining semi-thin sections of $1 \mu \mathrm{m}$. Tissue samples were stained with $1 \%$ toluidine blue. Ultrathin sections of $60-90 \mathrm{~nm}$ of thickness were made and mounted on copper mesh grids. These sections were contrasted with $\mathrm{Pb}$-citrate. Sections were studied through optical and transmission electron microscopy (JEOL/JEM 100SX). Eight to twelve sections were photographed, digitalized and twelve semi-thin and twelve ultra-thin sections per individual were analyzed using Scion Image Software.

From the images that showed lung capillaries, the capillary hematocrit was estimated by means of the stereologic point counting method (Weibel et al 1970/71) as Hto $=$ pe $/(\mathrm{pe}+\mathrm{pl})$, where pe and $\mathrm{pl}$ are the number of points of a grid that intersect erythrocytes and plasma, respectively. Also, diameter $\left(D_{e}\right)$ and the length of transversal axis of erythrocytes $\left(\mathrm{T}_{\mathrm{e}}\right)$ were measured using a morphometric software (Scion Image). For practical purposes the diameter was defined as the length of the mayor axis following the curvature of the cell and the transversal axis was traced perpendicular to that in the mid point of the diameter (Fig. 1).

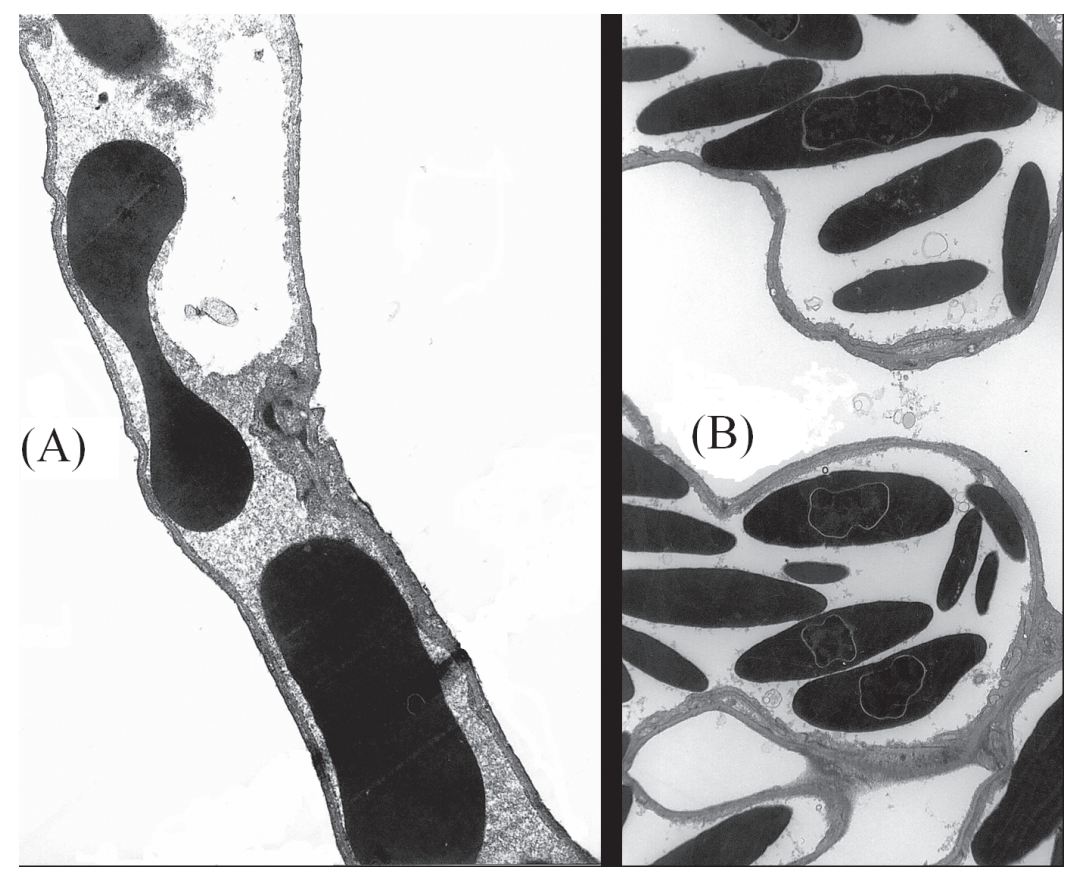

Fig. 1: Pulmonary capillary and red blood cells in (A) the bat Tadarida brasiliensis (7000X), and (B) the bird Nothoprocta perdicaria (1500X).

Capilar pulmonar y glóbulos rojos en (A) el murciélago Tadarida brasiliensis (7000X) y (B) la perdiz Nothoprocta perdicaria $(1500 \mathrm{X})$. 
Hematocrit and red blood cell size data from mammals and birds were analyzed with the Kruskall-Wallis, Wilcoxon signed, and MannWhitney U-tests, respectively. The frequency distribution of the hematocrit values (i.e., number of capillary with a particular hematocrit) among the species studied was compared with a $\chi^{2}$ test for both taxa.

To explore possible relations between pulmonary and hematological parameters, the present red blood cell diameter data and published data of respiratory surface area and thickness of the blood gas barrier from the same individuals of each species (Canals et al. 2005 b, Figueroa et al. in press) were analyzed by means of a cluster analysis and a principal component analysis based on standardized values $(\mathrm{z}=[\overline{\mathrm{x}}-\mathrm{sd}] / \mathrm{sd}$, sd the standard deviation) for each taxon (birds and mammals). The relationship between the red blood cell size and the mass specific oxygen diffusion capacity of the blood gas barrier $\left(\mathrm{D}_{\mathrm{L}} \mathrm{O}_{2} / \mathrm{M}_{\mathrm{b}}\right)$ was studied with correlation and regression analyses. That is a good estimator of the oxygen conductance independent of the body mass because the nearby linear relationship between $\mathrm{D}_{\mathrm{L}} \mathrm{O}_{2}$ and $\mathrm{M}_{\mathrm{b}}\left(\mathrm{D}_{\mathrm{L}} \mathrm{O}_{2} \propto \mathrm{M}_{\mathrm{b}}{ }^{1.08}\right.$, Weibel et al. 1992).
Independent phylogenetic contrasts (Felsenstein 1985) at order level were used considering the molecular phylogenetic hypothesis proposed by Murphy et al. (2001).

\section{RESULTS}

We did not find differences in the lung capillary hematocrit in mammals or in birds $\left(\chi^{2}{ }_{4}=6.67, \mathrm{P}=0.155\right.$ and $\mathrm{Z}=0.567, \mathrm{P}=0.564$ in Kruskall-Wallis and Wilcoxon tests for mammals and birds respectively) (Table 1). However, in birds we found a more symmetrical distribution than in mammals $\left(\chi^{2}{ }_{20}\right.$ $=41.05, \mathrm{P}=0.0037$; Fig. 2$)$. While mammals had a negative skewness in the frequency distribution of the capillary hematocrit $(-0.47$ in average), birds did not show skewness $(0.0032)$. In both taxonomic groups, the frequency distributions of the species were marginally similar $\left(\chi^{2}{ }_{12}=20.71, \mathrm{P}=0.06\right.$ and $\chi_{4}^{2}=8.51, \mathrm{P}=0.07$ in mammals and birds respectively). Considering the individual capillary segment as the study object, the lung capillary hematocrit ranged between 0 and $99 \%$ in mammals and between 0 and $89 \%$ in birds.

TABLE 1

Lung capillary hematocrit and the dimensions of the red blood cell in five mammalian and two avian species. $\mathrm{D}_{\mathrm{e}}$ and $\mathrm{T}_{\mathrm{e}}$ are the diameter and the transversal length of the erythrocyte respectively. Different letters indicate statistical differences at $\alpha=0.05$ in the Kruskall-Wallis a-posteriori nonparametric multiple comparison test

Hematocrito capilar pulmonar y dimensiones de los glóbulos rojos en cinco especies de mamíferos y dos especies de aves. $\mathrm{D}_{\mathrm{e}} \mathrm{y}_{\mathrm{e}}$ corresponden al diámetro longitudinal y transversal respectivamente. Letras diferentes indican diferencias significativas con un nivel $\alpha=0,05$ usando comparaciones múltiples post prueba de Kruskall-Wallis

\begin{tabular}{llll}
\hline Species & Capillary hematocrit $(\%)$ & $\mathrm{D}_{\mathrm{e}}(\mu \mathrm{m})$ & $\mathrm{T}_{\mathrm{e}}(\mu \mathrm{m})$ \\
\hline
\end{tabular}

Mammals

Abrothrix olivaceus

Abrothrix andinus

Phyllotis darwini

Tadarida brasiliensis

Myotis chiloensis

Birds

$$
\begin{aligned}
& 59.6 \pm 15.4 \\
& 69.8 \pm 4.7 \\
& 44.0 \pm 4.5 \\
& 65.0 \pm 7.5 \\
& 60.4 \pm 7.8
\end{aligned}
$$

$$
\begin{aligned}
& 5.74 \pm 0.40 \mathrm{bc} \\
& 4.73 \pm 0.21 \mathrm{~b} \\
& 7.05 \pm 0.22 \mathrm{c} \\
& 4.18 \pm 0.12 \mathrm{a} \\
& 4.38 \pm 0.17 \mathrm{ab}
\end{aligned}
$$

$$
\begin{aligned}
& 1.14 \pm 0.09 \mathrm{a} \\
& 1.54 \pm 0.09 \mathrm{ab} \\
& 1.23 \pm 0.06 \mathrm{ab} \\
& 1.22 \pm 0.11 \mathrm{ab} \\
& 2.56 \pm 0.13 \mathrm{~b}
\end{aligned}
$$

Nothoprocta perdicaria

Zenaida auriculata

\author{
$41.8 \pm 3.6$
}

$49.0 \pm 11.8$
$9.70 \pm 0.11$

$2.35 \pm 0.03$

$8.77 \pm 0.12$ 


\section{Mammals}

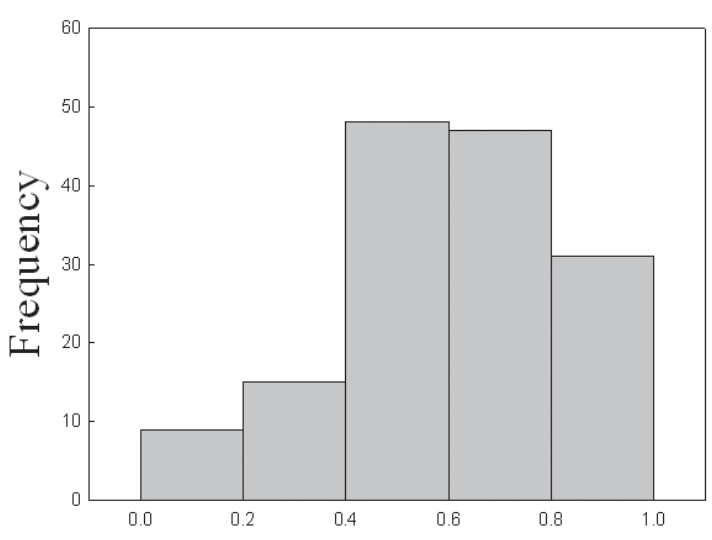

Birds

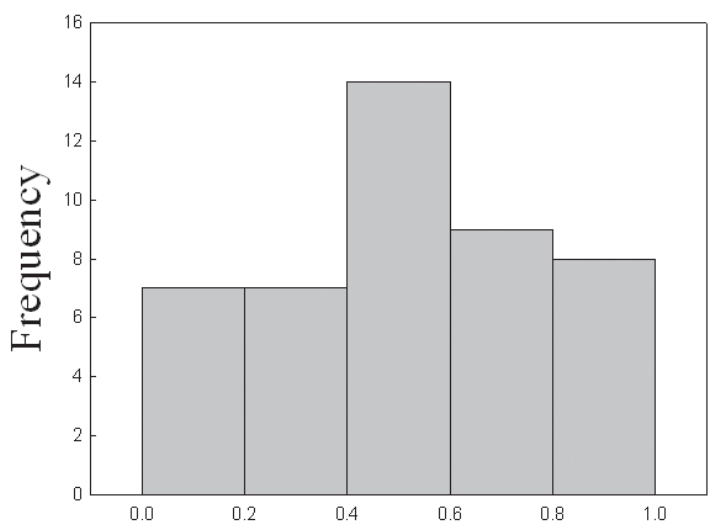

Fig. 2: Frequency histograms of the pulmonary capillary hematocrit in mammals and birds. All intervals were of the same length from 0 to $100 \%$ hematocrit: $1=0-20 \% ; 2=20-40 \% ; 3=$ $40-60 \% ; 4=60-80 \%$ and $5=80-100 \%$. Here the analysis unit is the capillary section.

Histograma de frecuencias del hematocrito capilar pulmonar en mamíferos y aves. Todos los intervalos del mismo largo, desde 0 a $100 \%$ de hematocrito: $1=0-20 \% ; 2=$ $20-40 \% ; 3=40-60 \% ; 4=60-80 \%$, and $5=80-100 \%$. Aquí la unidad de análisis es la sección capilar.

We found differences in erythrocyte size: $\chi_{4}^{2}=10.99, \mathrm{P}=0.026$ and $\chi^{2}{ }_{4}=10.32, \mathrm{P}=$ 0.035 for $\mathrm{D}_{\mathrm{e}}$ and $\mathrm{T}_{\mathrm{e}}$, respectively, in mammals; and $\mathrm{Z}=1.73, \mathrm{P}=0.08$ (the small $\mathrm{P}$ due to the sample size) and $\mathrm{Z}=1.73, \mathrm{P}=0.08 \mathrm{D}_{\mathrm{e}}$ and $\mathrm{T}_{\mathrm{e}}$ in birds, respectively. The diameter of the red blood cells $\left(\mathrm{D}_{\mathrm{e}}\right)$ in Zenaida auriculata was smaller than in the "non-flying" Nothoprocta perdicaria. In the bats $T$. brasiliensis and
Myotis chiloensis, $\mathrm{D}_{\mathrm{e}}$ was small and only comparable with that of $A$. andinus (Table 1).

When we contrasted erythrocyte size with the morphological determinants of the oxygen diffusion capacity of the lungs using a cluster analysis, we found that bats and the active flying bird $Z$. auriculata clustered close together. A similar result was obtained with the principal component analysis (Fig. 3).
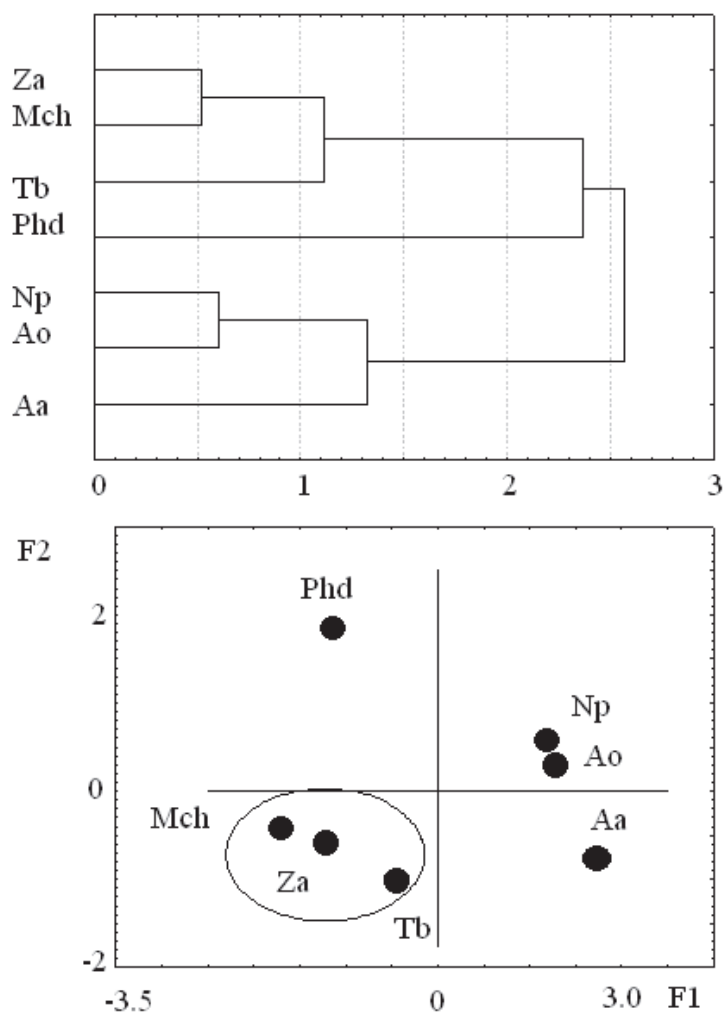

Fig. 3: Cluster analysis (up) and principal component analysis (down) based on standardized values of red blood cell diameter, respiratory surface area and thickness of the blood gas barrier (from Canals et al. 2005b, Figueroa et al. in press). Active flying animals marked with circles; $\mathrm{Tb}=$ Tadarida brasiliensis, $\mathrm{Mch}=$ Myotis chiloensis, $\mathrm{Phd}=$ Phyllotis darwini, Aa = Abrothrix andinus, Ao = Abrothrix olivaceus, $\mathrm{Np}=$ Nothoprocta perdicaria, $\mathrm{Za}=$ Zenaida auriculata.

Análisis de conglomerados (arriba) y análisis de componentes principales (abajo), basado en los valores estandarizados del diámetro del eritrocito, la superficie respiratoria y el grosor de la barrera aire-sangre (de Canals et al. 2005b y Figueroa et al. in press). Encerradas en un círculo los voladores activos; $\mathrm{Tb}=$ Tadarida brasiliensis, $\mathrm{Mch}=$ Myotis chiloensis, $\mathrm{Phd}=$ Phyllotis darwini, $\mathrm{Aa}=$ Abrothrix andinus, $\mathrm{Ao}=$ Abrothrix olivaceus, $\mathrm{Np}=$ Nothoprocta per dicaria, $\mathrm{Za}=$ Zenaida auriculata. 
We found a negative but non significant correlation $\left(\mathrm{r}=-0.44, \mathrm{~F}_{1,3}=0.75, \mathrm{P}=0.45\right)$ of erythrocyte diameter with $\mathrm{D}_{\mathrm{L}} \mathrm{O}_{2} / \mathrm{Mb}$ in mammals, but when we included additional data from the literature (Table 2) the correlation was significant $\left(\mathrm{r}=-0.46 ; \mathrm{F}_{1,17}=\right.$ 4.71, $\mathrm{P}=0.044$; Fig. 4). This result did not vary when we considered $M$. chiloensis as an out-groups $\left(\mathrm{r}=-0.47, \mathrm{~F}_{1,16}=4.56, \mathrm{P}=0.048\right)$ and neither when we considered only one average value per taxonomic category (order) $\left(\mathrm{r}=-0.79, \mathrm{~F}_{1,6}=9.62, \mathrm{P}<0.02\right)$. When we analyzed but corrected by phylogeny (independent contrasts) we obtain similar results $\left(\mathrm{r}=-0.824, \mathrm{~F}_{1,5}=10.567, \mathrm{P}<0.0226\right)$. Our bird data show a similar trend, the smaller the red blood cell, the higher $\mathrm{D}_{\mathrm{L}} \mathrm{O}_{2} / \mathrm{Mb}$. Unfortunately, the scarcity of available studies in which in which red blood cell size and $\mathrm{D}_{\mathrm{L}} \mathrm{O}_{2}$ avoid us to obtain robust results. With 15 points a non significant but negative correlation was found $\left(\mathrm{r}=-0.31, \mathrm{~F}_{1,12}=1.29\right.$, $\mathrm{P}=0.27)$.

\section{DISCUSSION}

The lung capillary hematocrit of the species studied was similar in mammals and birds. It showed great intra-individual variability, ranging from 0 to $99 \%$ in mammals and from 0 to $89 \%$ in birds. This means that there are capillary sections without red blood cells and other capillary sections with a very large number of them. This results agrees with those found in the classic study of Wearn et al. (1934) in which the not random switching of blood flow among pulmonary capillaries was described as the normal behavior of these vessels. Okada et al. (1994) found a considerable switching among capillaries which was not correlated with small variations in arterial pressure or cardiac output. Although the mechanism of switching remains unknown, it is thought that it is correlated with the continuously changing hematocrit of the blood that perfuses the pulmonary capillaries. In a similar vein, in vivo microscopic observation of individual pulmonary capillary segments showed that hematocrit varies constantly from zero to high values when a train of closely spaced red blood cells passes through the segment (Baumgartner et al. 2004).
Although the hematocrit differences among mammals did not reach statistical significance, the lung capillary hematocrit of the bats $M$. chiloensis and $T$. brasiliensis was high, specially considering that the mean pulmonary hematocrit is about a $90 \%$ of that of the systemic great vessels (Hsia et al. 1999). This is an expected result for bats, in which venous hematocrit over $60 \%$ are frequently reported (Neuweiler 2000). In particular in $T$. brasiliensis a venous hematocrit between 68 and $75 \%$ was found (Black \& Wiederhielm 1976). In addition, in other species of the genus Myotis hematocrits of $43 \%$ in M. myotis (9.3 g) and $60 \%$ in $M$. natteri (12.5 g) were reported (Neuweiler 2000). All these values are in the range of our data and could be attributed to the high oxygen requirements of flight. However, the hematocrit of A. andinus was also very high. Although $A$. andinus is a rodent that lives at high altitude which has high red blood cell counts, increased blood hemoglobin concentration and significant decrease in mean cell volume during seasons of high energetic requirements, the hematocrit has been reported constant and ranging from 49.9 to $53 \%$ throughout the year in this species (Rosenmann \& Ruiz 1993). If our result is a consequence of the high energetic requirements at high altitudes, we would expect a different response of the capillary hematocrit in the lungs than of the venous hematocrit. However, the lung capillary hematocrit of $A$. olivaceus, which inhabits low altitudes, also showed a high value. Finally, as expected, the hematocrit of $P$. darwini was low and similar to the $42.5 \%$, reported by Morrison et al. (1963a).

Differences in the red blood cell size among species reported here suggest that this parameter is highly correlated with the locomotion style. In both mammals and bird species the same trend towards to exhibits a small size in active flying animals was found. In addition, the high Andean rodent $A$. andinus and the bats had a very small red blood cell size, suggesting a positive association between erythrocyte size and oxygen demand.

Correlation of erythrocyte size with the diffusing characteristics of the lungs produced a non-phylogenetic clustering with a group constituting by the bats and $Z$. auriculata; revealing similar functional response in unrelated species. This cluster suggests also that 


\section{TABLE 2}

Red blood cell diameter $\left(\mathrm{D}_{\mathrm{e}}\right)$, oxygen diffusion capacity air-erythrocyte $\left(\mathrm{DLO}_{2}\right)$ and mass-specific oxygen diffusion capacity $\left(\mathrm{D}_{\mathrm{t}} \mathrm{O}_{2} / \mathrm{M}_{\mathrm{b}}\right)$ in several mammals and birds. Data of TGR from this study ${ }^{1}$, Gregory $(2000)^{2}$, Banerjee et al. (1962) ${ }^{3}$, Bartels et al. (1979) $)^{4}$, Goniakowska-Witalinska (1976) ${ }^{5}$, Altman \& Dittmer (1974) $)^{6}$, Bartsch et al. (1937) $)^{7}$, Mushi et al. $(1999)^{8}$, Gulliver (1875) ${ }^{9}$. Data of $\mathrm{D}_{\mathrm{L}} \mathrm{O}_{2}$ and $\mathrm{D}_{\mathrm{L}} \mathrm{O}_{2} / \mathrm{M}_{\mathrm{b}}$ from Canals et al. (2005b) ${ }^{10}$, Figueroa et al. (in press) ${ }^{11}$, Maina (2002) ${ }^{13}$ and Gehr et al. $(1981)^{12}$. Values of oxygen diffusion capacity $\mathrm{D}_{\mathrm{L}} \mathrm{O}_{2}$ of some species (Canals et al. $2005 \mathrm{~b}$ and Figueroa et al. in press) were estimated from the tissue oxygen diffusion capacity $\mathrm{D}_{\mathrm{t}} \mathrm{O}_{2}$ by using $\mathrm{D}_{\mathrm{L}} \mathrm{O}_{2}=\mathrm{D}_{\mathrm{t}} \mathrm{O}_{2} / 10$ (Canals et al. 2005b)

Diámetro del glóbulo rojo $\left(\mathrm{D}_{\mathrm{e}}\right)$, capacidad de difusión de oxígeno $\left(\mathrm{D}_{\mathrm{L}} \mathrm{O}_{2}\right)$ y capacidad de difusión de oxígeno masa-específica $\left(\mathrm{D}_{\mathrm{t}} \mathrm{O}_{2} / \mathrm{M}_{\mathrm{b}}\right.$ ) en mamíferos y aves. Datos de TGR de este estudio ${ }^{1}$, Gregory $(2000)^{2}$, Banerjee et al. (1962) ${ }^{3}$, Bartels et al $(1979)^{4}$, Goniakowska-Witalinska $(1976)^{5}$, Altman \& Dittmer $(1974)^{6}$, Bartsch et al. (1937) $)^{7}$, Mushi et al. (1999) ${ }^{8}$, Gulliver $(1875)^{9}$. Datos de $\mathrm{D}_{\mathrm{L}} \mathrm{O}_{2}$ y $\mathrm{D}_{\mathrm{L}} \mathrm{O}_{2} / \mathrm{M}_{\mathrm{b}}$ de Canals et al. (2005b) $)^{10}$, Figueroa et al. (in press) ${ }^{11}$, Maina (2002) ${ }^{13} \mathrm{y}$ Gehr et al.

$(1981)^{12}$. Los valores de $\mathrm{D}_{\mathrm{L}} \mathrm{O}_{2}$ de algunas especies (datos de Canals et al. 2005b y Figueroa et al. in press) fueron estimados a partir de la capacidad de difusión de oxígeno de la barrera $\mathrm{D}_{\mathrm{t}} \mathrm{O}_{2}$ a partir de $\mathrm{D}_{\mathrm{L}} \mathrm{O}_{2}=\mathrm{D}_{\mathrm{t}} \mathrm{O}_{2} / 10$ (Canals et al 2005b)

\begin{tabular}{|c|c|c|c|c|}
\hline$\left(\mathrm{mL} \mathrm{O}_{2} \mathrm{~s}^{-1} \mathrm{mbar}^{-1}\right)$ & $\mathrm{Mb}(\mathrm{g})$ & $\mathrm{D}_{\mathrm{e}}(\alpha \mathrm{m})$ & $\begin{array}{c}\mathrm{D}_{\mathrm{L}} \mathrm{O}_{2} \\
\left(\mathrm{x} 10^{-5} \mathrm{~mL} \mathrm{O}_{2} \mathrm{~s}^{-1} \mathrm{mbar}^{-1} \mathrm{~g}^{-1}\right)\end{array}$ & $\mathrm{D}_{\mathrm{L}} \mathrm{O}_{2} / \mathrm{M}_{\mathrm{b}}$ \\
\hline \multicolumn{5}{|l|}{ Mammals } \\
\hline Mus musculus ${ }^{2,12}$ & 42 & 6.80 & 0.00213 & 5.07143 \\
\hline Rattus rattus ${ }^{2,12}$ & 457 & 7.50 & 0.01830 & 4.00438 \\
\hline Phyllotis darwini ${ }^{1,11}$ & 75 & 7.05 & 0.00469 & 6.26473 \\
\hline Abrothrix olivaceus ${ }^{1,10}$ & 26 & 5.74 & 0.00075 & 2.86198 \\
\hline Abrothrix andinus ${ }^{1,10}$ & 26 & 4.73 & 0.00128 & 5.0434 \\
\hline Cavia porcellus 2,12 & 429 & 7.10 & 0.01790 & 4.17249 \\
\hline Myotis chiloensis ${ }^{1,11}$ & 6 & 4.38 & 0.00156 & 26.0731 \\
\hline Tadarida brasiliensis ${ }^{1,10}$ & 11 & 4.18 & 0.00094 & 8.32943 \\
\hline Oryctolagus cuniculus ${ }^{2,12}$ & 3,560 & 7.50 & 0.09170 & 2.57584 \\
\hline Canis familiaris $^{2,12}$ & 21,350 & 7.60 & 1.31275 & 6.14871 \\
\hline Camelos dromedarius ${ }^{3,12}$ & 231,700 & 7.70 & 4.93700 & 2.13077 \\
\hline Giraffa camelopardalis ${ }^{2,12}$ & 383,000 & 5.50 & 11.17200 & 2.91697 \\
\hline Capra hircus ${ }^{2,12}$ & 20,900 & 4.00 & 1.06200 & 5.08134 \\
\hline Ovis aries ${ }^{2,12}$ & 21,800 & 5.20 & 1.55400 & 7.12844 \\
\hline Bos taurus ${ }^{2,12}$ & 700,000 & 5.80 & 29.34600 & 4.19229 \\
\hline Equus caballus ${ }^{2,12}$ & 510,000 & 6.20 & 34.08000 & 6.68235 \\
\hline Homo sapiens ${ }^{2,12}$ & 74,000 & 8.00 & 2.47000 & 3.33784 \\
\hline Suncus etruscus ${ }^{4,12}$ & 3 & 5.50 & 0.00018 & 6.92308 \\
\hline Crocidura russula ${ }^{4,12}$ & 12 & 7.00 & 0.00053 & 4.34426 \\
\hline \multicolumn{5}{|l|}{ Birds } \\
\hline Zenaida auriculata ${ }^{1,11}$ & 141 & 8.77 & 0.01666 & 11.819 \\
\hline Nothoprocta perdicaria ${ }^{1,11}$ & 398 & 9.70 & 0.01051 & 2.6406 \\
\hline Struthio camelus ${ }^{8,13}$ & 45,000 & 15.40 & 2.93000 & 6.5111 \\
\hline Anser anser ${ }^{9,13}$ & 3,838 & 12.80 & 0.17200 & 4.4815 \\
\hline Gallus gallus ${ }^{5,13}$ & 2,141 & 11.20 & 0.03300 & 1.5413 \\
\hline Columba libia ${ }^{6,13}$ & 216 & 13.30 & 0.02000 & 9.2593 \\
\hline Dromaius novaehollandiae $e^{9,13}$ & 30,000 & 15.00 & 0.00500 & 0.0166 \\
\hline Passer domesticus ${ }^{7,13}$ & 26 & 11.29 & 0.00300 & 11.765 \\
\hline Sturnus vulgaris ${ }^{7,13}$ & 73 & 10.37 & 0.00500 & 6.8871 \\
\hline Falco tinnunculus ${ }^{9,13}$ & 66 & 13,4 & 0.00500 & 7.5758 \\
\hline Larus canus ${ }^{9,13}$ & 302 & 12,9 & 0.01000 & 3.3113 \\
\hline Larus ridibundus ${ }^{9,13}$ & 253 & 12,1 & 0.01100 & 4.3478 \\
\hline Streptopelia decaota ${ }^{9,13}$ & 189 & 11,9 & 0.01200 & 6.3492 \\
\hline Lanius collaris $^{9,13}$ & 33 & 11,4 & 0.00200 & 6.1162 \\
\hline
\end{tabular}




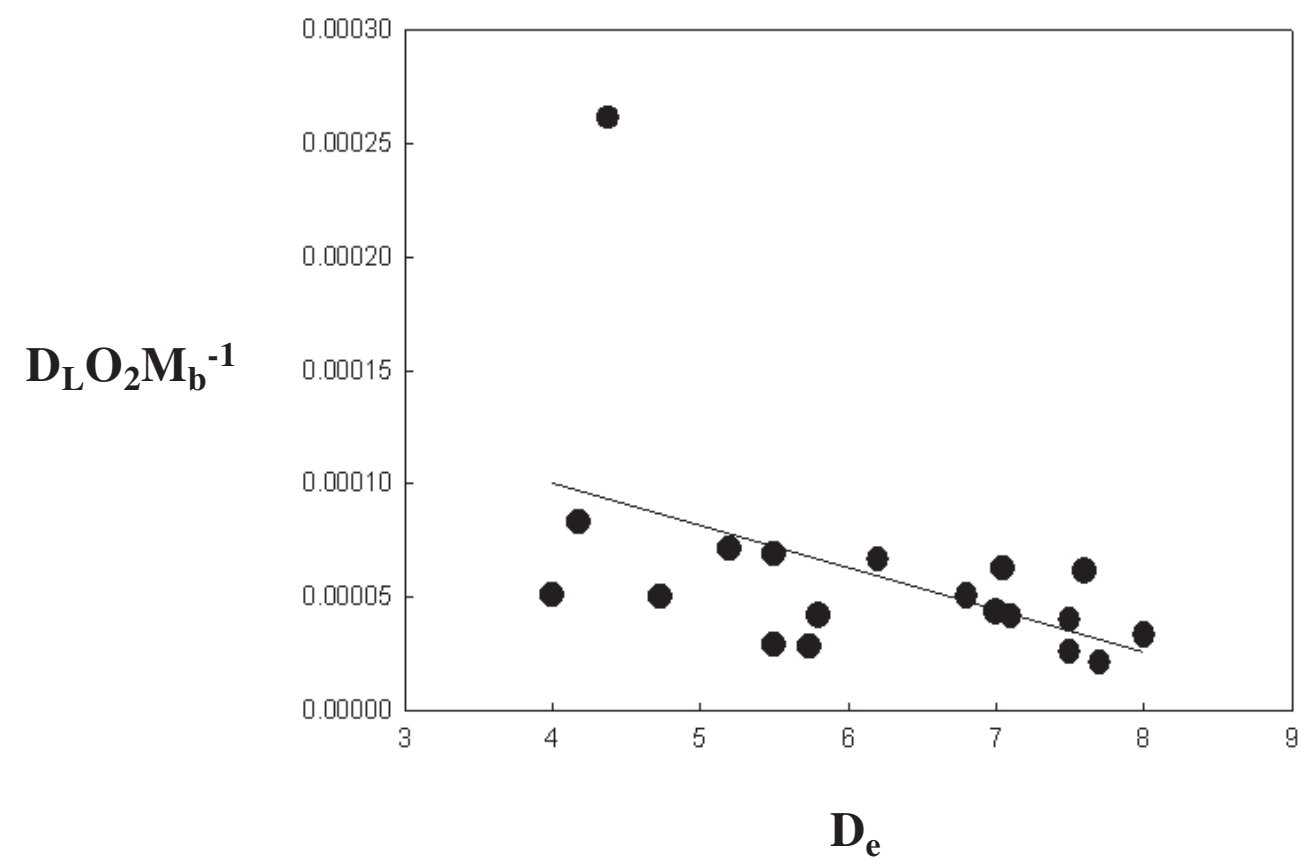

Fig. 4: Regression line between the red blood cell size $\left(\mathrm{D}_{\mathrm{e}}\right)$ and the mass specific oxygen diffusion capacity of the blood gas barrier $\left(\mathrm{D}_{\mathrm{L}} \mathrm{O}_{2} / \mathrm{M}_{\mathrm{b}}\right)$ in mammals.

Regresión lineal entre el diámetro del glóbulo rojo $\left(D_{e}\right)$ y la capacidad de difusión de oxígeno masa-específica $\left(D_{L} O_{2} / M_{b}\right)$ en mamífero.

the direction of the anatomical changes is governed mainly by the requirements of flight. Although the more recent ancestors of mammals and birds diverged at different times from reptiles lineages, birds in the upper Jurassic (150 million years ago) and bats in the Eocene (50 million years ago), and their anatomical pulmonary adjustments associated with flight differ enormously (Maina 2000a, 2000b), at least the anatomical characteristics of the red blood cells and the air-blood barrier vary in the same direction in both taxa. The most important morphological and physiological refinements associated to the oxygen uptake capacity of bats in flight are: large heart with a huge cardiac output (Jurgens et al. 1981, Canals et al. 2005); high hematocrit, hemoglobin concentration, erythrocyte count and blood oxygen-carrying capacity (Wolk \& Bogdanowics 1987), thin airblood barrier and high oxygen diffusion capacity (Maina \& King 1984, Maina 2000a, 2000b, Canals et al. 2005); and efficient capillary blood supply to the flight muscles (Mathieu-Costello 1992). The fundamental adaptative features reported in birds are cross-current mechanisms, para-bronchi, air-sacs and unidirectional air flow in the avian airway, short pulmonary circulatory time and, as in bats, large hearts and thin airblood barriers (Maina 1998, 2000a, 2000b).

Small red blood size and high oxygen diffusion capacity appears to be correlated; the latter as a consequence of a thin air-blood barrier and a large respiratory surface. Although regression analyses of our data did not reach statistical significance, when data from literature were included a clear negative slope between the red blood diameter and the oxygen diffusion capacity was evident in mammals. Although a negative tendency seems to be occurring in birds, it did not reach a significant level, probably because of the small number of data. Small red blood size and as a consequence a high area/volume ratio have been associated with a facilitated oxygen diffusion, an increase of the hemoglobin concentration and an increase in erythrocyte count without increasing the blood viscosity (Promislow 1991, Rosenmann \& Ruiz 1993), all these factors operating in the same direction of a thin air-blood barrier and a large respiratory surface, and in consequence a high oxygen conductance. 


\section{ACKNOWLEDGEMENTS}

This work was supported by the FONDECYT 1040649 grant to MCL. We thank Dr. Lafayette Eaton for improving the English.

\section{LITERATURE CITED}

ALTMANN PL \& DS DITTMER (1974) Biology data book. Vol III: 1841-1842. Federations of American Societies for Experimental Biology, Bethesda, Maryland, USA.

BANERJEE S, RC BHATTACHARJEE \& TI SINGH (1962) Hematological studies in the normal adult Indian camel (Camelus dromedarius). American Journal of Physiology 203: 1185-1187.

BARTELS H, R BARTELS, R BAUMANN, R FONS, KD JURGENS \& P WRIGHT (1979) Blood oxygen transport of two shrew species ( $S$. etruscus and $C$. russula). American Journal of Physiology Regulatory Integrative and Comparative Physiology 236: R221-224.

BARTSCH P, WH HALL, W ROSENZWEIG \& S SALMAN (1937) Size of red blood corpuscles and their nucleus in fifty north American birds. The Auk October: 516-519.

BLACK LL \& CA WIEDERHIELM (1976) Plasma oncotic pressures and hematocrit in an intact anaesthestized bat. Microvascular Research 12:55-58.

BAUMGARTNER WAJr, AJ PETERSON, RCJr PRESSON, N TANABE, E JARYSZAK \& WWJr WAGNER (2004) Blood flow switching among pulmonary capillaries during high hematocrit. Journal of Applied Physiology 97:522-526.

BLACK CP \& SM TENNEY (1980) Oxygen transport during progressive hypoxia in high-altitude and sealevel waterfowl. Respiration Physiology 39: $217-$ 239.

CANALS M, C ATALA, B GROSSI \& J IRIARTE-DÍAZ (2005a) Heart and lung size of several small bats. Acta Chiropterologica 7: 65-72.

CANALS M, C ATALA, R OLIVARES, F GUAJARDO, DP FIGUEROA, P SABAT \& M ROSENMANN (2005b) Functional and structural optimization of the respiratory system of the bat Tadarida brasiliensis (Chiroptera, Molossidae): does airway geometry matter? The Journal of Experimental Biology 208:3987-3995.

CAREY C \& ML MORTON (1976) Aspects of circulatory physiology of montane lowland birds. Comparative Biochemistry and Physiology 54A: 61-74.

CARPENTER FL (1975) Bird hematocrits: effect of high altitude and strength of flight. Comparative Biochemistry and Physiology 50A: 415-417.

FELSENSTEIN J (1985) Phylogenies and the comparative method. American Naturalist 125: 1-15.

FIGUEROA D, R OLIVARES, M SALABERRY, P SABAT \& M CANALS (in press) Interplay between the morphometry of the lungs and the mode of locomotion in birds and mammals. Biological Research. Vol: número de páginas

GEHR P, DK MWANGI, A AMMANN, GMO MALOIY, CR TAYLOR \& ER WEIBEL (1981) Design of the mammalian respiratory system. V. Scaling morphometric pulmonary diffusing capacity to body mass: wild and domestic mammals. Respiration Physiology 44: 61-86.
GONIAKOWSKA-WITALINSKA L \& W WITALINSKI (1976) Evidence for a correlation between the number of marginal microtubules and the size of vertebrate erythrocytes. Journal of Cellular Science 22: $397-401$

GREGORY TR (2000) Nucleotypic effect without nuclei: genome size and erythrocyte size in mammals. Genome 43: 895-901.

GULLIVER G (1875) On the size and shape of red corpuscles of the blood of vertebrates, with drawings of them to a uniform scale, and extended and revised tables of measurements. Proceedings of the Royal Society of London 1875: 474-495.

HSIA CCW, DG McBRAYER \& M RAMANATHAN (1995) Reference values of pulmonary diffusing capacity during exercise by a rebreathing technique. American Journal of Respiratory Critical Care Medicine 152: 658-665.

HSIA CCW, RL JHONSON Jr \& D SHAH (1999) Red cell distribution and the recruitment of pulmonary diffusing capacity. Journal of Applied Physiology 86: $1460-1467$.

JÜRGENS JD, H BARTELS \& R BARTELS (1981) Blood oxygen transport and organ weight of small bats and small non-flying mammals. Respiration Physiology 45: 243-60.

KEYS GC, RC FLEISCHER \& SI ROTHSTEIN (1986) Relationships between elevation, reproduction and the hematocrit level of brown-hesded cowbirds. Comparative Biohemistry and Physiology 83A: 765-769.

LECHNER A (1976) Respiratory adaptations in burrowing pocket gophers from sea level and high altitude. Journal of Applied Physiology 41: 168-173.

LECHNER AJ (1985) Pulmonary design in a microchiropteran bat (Pipistrellus subflavus) during hibernation. Respiration Physiology 59: 301-312.

MAINA JN (1998) The lungs of the flying vertebratesbirds and bats: is their structure optimized for this elite mode of locomotion? In: Weibel ER, CR Taylor \& L Bolis (eds) Principles of animal design: the optimization and symmorphosis debate: 177185. Cambridge University Press, Cambridge, United Kingdom.

MAINA JN (2000a) What it takes to fly: the structural and functional respiratory refinements in birds and bats. Journal of Experimental Biology 203: 3045-64.

MAINA JN (2000b) Comparative respiratory morphology: themes and principles in the design and construction of the gas exchangers. Anatomical Records 261: 25-44.

MAINA JN (2002) Some recent advances on the study and understanding of the functional design of the avian lung: morphological and morphometric perspectives. Biological Reviews 77: 97-152.

MAINA JN, SP THOMAS \& DM DALLS (1991) A morphometric study of bats of different size: correlations between structure and function of the chiropteran lung. Philosophical Transactions of the Royal Society of London B333: 31-50.

MAINA JN \& AS KING (1984) The structural functional correlation in the design of the bat lung. A morphometric study. The Journal of Experimental Biology 111: 43-63.

MATHIEU-COSTELLO O, JM SZEWCSAK, RB LOGERMAN \& PJ AGEY (1992) Geometry of blood-tissue exchange in bat flight muscle compared with bat hindlimb and rat soleus muscle. American Journal of Physiology 262: 955-65.

MORRISON P, K KERST \& M ROSENMANN (1963a) 
Hematocrit and hemoglobin levels in some Chilean rodents from high and low altitude. International Journal of Biometeorology 7: 45-50.

MORRISON P, K KERST, C REYNAFARJE \& J RAMOS (1963b) Hematocrit and hemoglobin levels in some Peruvian rodents from high and low altitude. International Journal of Biometeorology 7: 51-58.

MURPHY WJ, E EIZIKIR, WE JOHNSON, YP ZHANG, OA RYDER \& SJ O'BRIEN (2001) Molecular phylogenetics and the origins of placental mammals. Nature 409: 614-618.

MUSHI EZ, MG BINTA, RG CHABO, JFW ISA \& RW KAPAATA (1999) Selected hematological values of farmed ostriches (Struthio camelus) in Botswana. Journal of Veterinary Diagnostic Investigation 11: 372-374.

NEUWEILER G (2000) The blood. In: Neuweiler G (ed) The biology of bats: 53-55. Oxford University Press, Oxford, United Kingdom.

NOVOA FF, M ROSENMANN \& F BOZINOVIC (1991) Physiological responses of four passerine species to simulated altitudes. Comparative Biochemistry and Physiology 99A: 179-183

NOVOA FF, G RUIZ \& M ROSENMANN (2002) El oxígeno y la vida en alta altitud. In: Bozinovic F (ed) Fisiología ecológica y evolutiva: 227-246. Ediciones Universidad Católica de Chile, Santiago, Chile.

OKADA O, RG PRESSON Jr, PS GODBEY, RL CAPEN \& WW WAGNER Jr (1994) Capillary perfusion patterns in single alveolar walls. Journal of Applied Physiology 76: 380-386.

PROMISLOW DE (1991) The evolution of mammalian blood parameters. Patterns and their interpretation. Physiological Zoology 64: 393-431.
RAPAPORT E, H KUIDA, FW HAYNES \& L DEXTER (1996) Pulmonary red cell and plasma volumes and pulmonary hematocrit in the normal dog. American Journal of Physiology 185: 127-132.

ROSENMANN M \& G RUIZ (1993) Seasonal changes of blood values in the Andean mouse Abrothrix andinus. Comparative Biochemistry and Physiology 105A: 119-123.

VISCOR G \& JF FUSTER (1987) Relationships between morphological parameters in birds with different flying habits. Comparative Biochemistry and Physiology 87A: 231-249.

VISCOR G, MS MARQUES \& J PALOMEQUE (1985) Cardiovascular and organ weight adaptations as related to flight activity in birds. Comparative Biochemistry and Physiology 82A: 597-599.

WOLK E \& W BOGDANOWICS (1987) Hematology of the hibernating bat, Myotis daubentoni. Comparative Biochemistry and Physiology 88A: 637-39.

WEARN JT, AC ERNSTENE, AW BROMER, JS BARR, WJ GERMAN \& LJ ZSCHIESCHE (1934) The normal behavior of the pulmonary blood vessels with observations of the intermittence of the flow of blood in the arterioles and capillaries. American Journal of Physiology 109: 236-256.

WEIBEL ER (1970/71) Morphometric estimation of pulmonary diffusion capacity. Respiration Physiology 11: 54-75.

WEIBEL ER, CR TAYLOR \& H HOPPELER (1992) Variations in function and design: testing symmorphosis in the respiratory system. Respiration Physiology 87: 325-348. 